\title{
Microbial loop in an oligotrophic pelagic marine ecosystem: possible roles of cyanobacteria and nanoflagellates in the organic fluxes
}

\author{
A. Hagström*, F. Azam**, A. Andersson*, J. Wikner*, F. Rassoulzadegan \\ Station Marine de Villefranche-Sur-Mer, Station Zoologique, Université P. et M. Curie, F-06230 Villefranche-Sur-Mer, France
}

\begin{abstract}
In an attempt to quantify the organic fluxes within the microbial loop of oligotrophic Mediterranean water, organic pools and production rates were monitored. The production of cyanobacteria and its dynamics dominated the overall productivity in the system. The largest standing stock was that of the bacterioplankton and its growth consumed $8.3 \mu \mathrm{g} \mathrm{Cl}^{-1} \mathrm{~d}^{-1}$, hence about $60 \%$ of the primary production was required for bacterial growth. Using the MiniCap technique, we measured a predation on bacteria of $2.6 \times 10^{4}$ bacteria $\mathrm{ml}^{-1} \mathrm{~h}^{-1}$. This was in good agreement with the bacterial production rate of $2.3 \times 10^{4}$ cells $\mathrm{ml}^{-1} \mathrm{~h}^{-1}$ Thus, growth and predation were balanced for heterotrophic bacterioplankton. Almost all of this predation on bacteria was due to organisms passing a $12 \mu \mathrm{m}$ Nuclepore filter. This raises the question of what mechanisms channel $60 \%$ of primary production into bacteria. We therefore outlined a mass-balance model to illustrate routes that could explain this transfer. According to our model the main flux route is cyanobacteria and concomitantly consumed heterotrophic bacteria carbon into bacterivores. A substantial fraction of the bacterivore and the microplankton carbon is released by excretion and/or cell lysis, to be used by the heterotrophic bacterioplankton. About $86 \%$ of the autotrophic production is balanced by respiration due to heterotrophic bacteria and protozoa, leaving $6 \%$ of the primary production to higher trophic levels. This scenario should apply to ecosystems where bacterial production rate is high and comparable to primary production, and the dominant primary producers are cyanobacteria. A significant fraction of the photosynthetically fixed carbon will be mineralized within a simple microbial loop, thus rendering it an energy sink in the foodweb.
\end{abstract}

\section{INTRODUCTION}

The development of methods to measure bacterial standing stocks and production rates has shown that a large portion of the carbon assimilated through primary production passes through bacterioplankton (Hobbie et al. 1977, Hagström et al. 1979, Fuhrman \& Azam 1980, 1982). Thus, the realization that bacterioplankton is a major pathway in the flux of material and energy in pelagic marine ecosystems, has generated considerable interest in the structure and functioning of this part of the foodweb (Joint \& Pomeroy 1983, Laws et al.

Permanent addresses:

- Department of Microbiology, University of Umeå, S-901 87 Umeå, Sweden

- Institute of Marine Resources, A/018, Scripps Institution of Oceanography, University of California, San Diego, La Jolla, California 92093, USA
1984, Ducklow et al. 1986, Azam \& Cho 1987). Specific questions central to this issue are: (1) Since bacterioplankton are osmo-trophic, what physiological and trophic mechanisms channel one-half of the primary production into the dissolved organic matter (DOM) pool? (2) Does the bacterioplankton production form the energetic base of a microbial foodweb?

Available data relevant to the above questions have been used to hypothesize the existence of a microbial loop' in the pelagic marine foodweb (Azam et al. 1983). This hypothesis envisions phytoplankton-derived DOM as supporting bacterioplankton production, a part of which may be transferred to the traditional grazing food-chain via bacterioplankton, nanoflagellate, and ciliate links. We have attempted to quantify the organic fluxes within the 'microbial loop' and to determine how tightly coupled these fluxes are in response to the diel variations in primary production and DOM inputs. 


\section{MATERIALS AND METHODS}

Sampling site. Measurements of microbial components and their dynamics were made in oligotrophic Mediterranean sea water collected at Sampling point $b$, Villefranche-Sur-Mer, France (Rassoulzadegan \& Sheldon 1986). Water was collected on the morning of the experiment and transferred to a $50 \mathrm{l}$ glass carboy which was kept filled with seawater from the previous day. The carboy was incubated in an open temperaturecontrolled container.

Primary production. Water samples $(100 \mathrm{ml})$ were incubated for $3 \mathrm{~h}$, during each $3 \mathrm{~h}$ interval between 06:00 and $21: 00 \mathrm{~h}$ with the addition of $10 \mu \mathrm{Ci}$ of carrierfree $\mathrm{NaH}^{14} \mathrm{CO}_{3}$. Cells in different size fractions were collected on filters (Nuclepore). Subsamples $(15 \mathrm{ml}$ ) of incubated water were filtered in parallel through 3,1 and $0.2 \mu \mathrm{m}$ filters, and the acid stable fraction of the 0.2 -filtrate was collected. Samples were counted in a liquid scintillation counter (Beckman Instruments 1801). Uptake was measured in both light and dark bottles, and dark values were subtracted. The assimilation of carbon was calculated as described by Gargas (1975).

Bacterial secondary production. The protocol of Fuhrman \& Azam (1982) for measuring ${ }^{3} \mathrm{H}$-thymidine incorporation was followed. Moles of thymidine were converted to cells produced with the conversion factor $1.7 \times 10^{18}$ cells $\mathrm{mol}^{-1}$.

Cell count and size determinations. Epifluorescence microscopy was used to determine cell numbers. Live cyanobacteria were counted in green light excitation. Preserved and stained (Dapi) samples were counted for heterotrophic bacteria, and nanoflagellates (Porter \& Feig 1980). Ciliates preserved in formaldehyde were counted in an inverted microscope (Rassoulzadegan \& Gostan 1976). Cell size was determined from photographs taken in epifluorescence (Zeiss M63 camera, Kodak technical pan film 2415 for cyanobacteria and Kodak Echtachrome for Dapi stained samples). Magnification on negatives was $\times 315$. Cells were digitized using a graphic's tablet (Tektronix 4956, 4051) (Andersson et al. 1986). The measured cell-volume of heterotrophic bacteria was recalculated to bacterial carbon using a conversion factor of $9.6 \mathrm{fg} \mathrm{C} \mathrm{Cell}^{-1}$. This number is low compared to values given by Bjørnsen (1986), Bratbak (1985) and Lee \& Fuhrman (1987). From these studies it is evident that the procedure of measuring cell dimensions from pictures of fluorescent bacteria is a crucial step in the protocol used to determine bacterial biomass. In our determination of biovolume we have not applied the same strict criteria as Lee \& Fuhrman (1987) to avoid the effect of the fluorescent halo surrounding the bacteria. As a consequence we have used an estimate of $0.14 \mathrm{pg} \mathrm{C} \mu \mathrm{m}^{-3}$ bacterial biomass, determined using the same procedure to measure cell-dimensions as in the present study (Larsson \& Hagström 1982). For the larger and autofluorescent cyanobacteria the halo effect is a lesser problem, hence biovolume was converted to biomass carbon using a carbon content of $0.40 \mathrm{pg} \mathrm{C} \mathrm{\mu m}^{-3}$ (Takahashi et al. 1985)

Predation on bacteria. The MiniCap method of Wikner et al. (1986) was used to determine rate of predation on heterotrophic bacteria. Minicells prepared from transformed E.coli M2141 carrying the plasmids pACYC184 and pBR322 were labelled using ${ }^{35} \mathrm{~S}$ methionin. The incorporation of label into specific proteins gives each type of minicell a specific marker. Minicells are incubated in sea water and the amount of marker protein is determined and calculated to give the number of remaining minicells. Addition of a second type of minicell as internal standard allows quantitative recovery of the remaining minicells.

Chemostat experiment. Continuous cultures of heterotrophic bacteria (sea water culture; Ammerman et al. 1984) and cyanobacteria (Synecococcus sp.) were mixed in a 2-stage chemostat containing nano-flagellates (Ochromonas sp.). Cultures were run for $10 \mathrm{~d}$ before sampling and then sampled every day for $5 \mathrm{~d}$. Concentrations of cells were determined with epifluorescence direct count.

\section{RESULTS AND DISCUSSION}

In an attempt to quantify the organic fluxes within the microbial loop we conducted a time-series experiment monitoring changes in organic pools and production rates. The experiment was conducted in a carboy in order to circumvent problems due to advection, mixing, and migration of organisms. Water was collected on the morning of the experiment and transferred to a $50 \mathrm{l}$ glass carboy. At intervals water was drawn via a siphon, and subsamples distributed to the different measurements.

\section{Primary productivity in size-fractions}

Primary production in the carboy was measured every $3 \mathrm{~h}$. The integrated assimilation for $24 \mathrm{~h}$ 109:00 to 09:00 h) was $14.1 \mu \mathrm{g} \mathrm{C}{ }^{-1}$ (Fig. 1, Table 1). Small cells, filterable through $1.0 \mu \mathrm{m}$ Nuclepore filters, were responsible for $44 \%$ of the carbon fixation. Epifluorescence microscopy showed that this fraction contained unicellular cyanobacteria; only a few objects showing chlorophyll a fluorescence. We found that $23 \%$ of the cyanobacteria were retained by the $1.0 \mu \mathrm{m}$ Nuclepore filters. To calculate the total production due to 


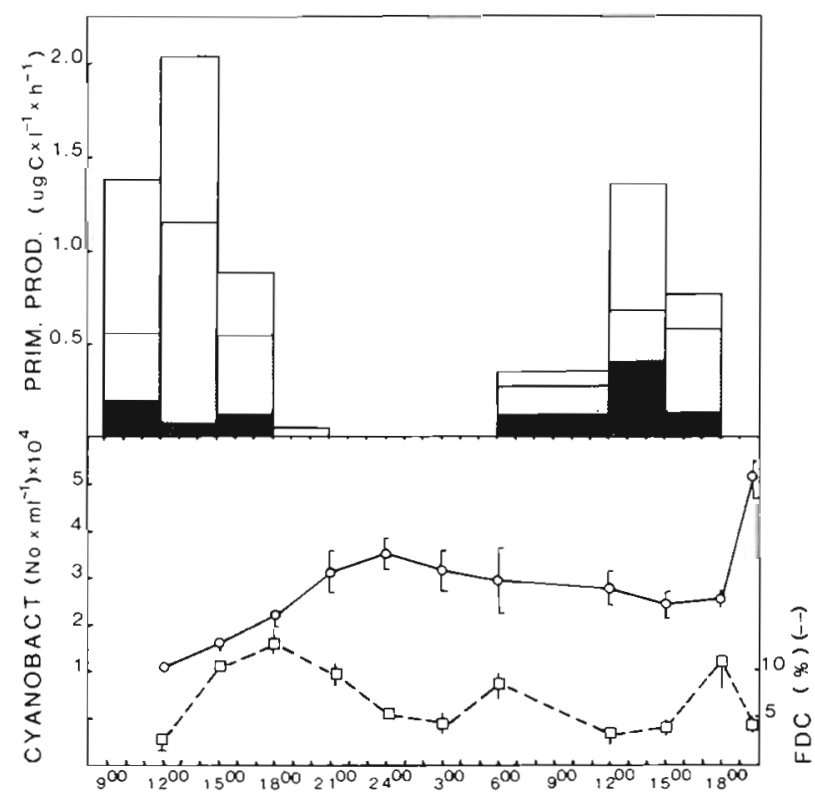

Fig. 1. Diel variation of primary production as measured by the ${ }^{14} \mathrm{C}$-method (upper panel). Dark area represents ${ }^{14} \mathrm{C}$ DOM passing a $0.2 \mu \mathrm{m}$ Nuclepore filter; grey area, ${ }^{14} \mathrm{C}$ assimilation in organisms passing a $1 \mu \mathrm{m}$ Nuclepore filter. Lower panel: Abundance of cyanobacteria (circles) and frequency of dividing cyanobacteria (squares); bars: \pm Standard Error (SE)

cyanobacteria the contribution of the retained cyanobacteria was added, assuming that they had the same per cell production as those passing the filter. This calculation shows $57 \%$ of the primary production to be due to cyanobacteria. Thus the total production of cyanobacteria amounts to $8.1 \mu \mathrm{g} \mathrm{C} 1^{-1} \mathrm{~d}^{-1}$. Primary production in the $>1 \mu \mathrm{m}$ fraction constituted $32 \%$ of the total producion and was dominated by flagellates. Exudation (organic ${ }^{14} \mathrm{C}$ passing a $0.2 \mu \mathrm{m}$ Nuclepore filter) averaged $11 \%$ of the primary production. (Table 1).
The large contribution of cyanobacteria sized organisms to the primary production is essential to our model of the 'microbial loop'; it was therefore important to examine the data on uptake of ${ }^{14} \mathrm{C}$ by the autotrophs. To avoid contribution from large organisms into the smaller size fractions we filtered in parallel. Thus ${ }^{14} \mathrm{C}$ labeled fragments from the $>1 \mu \mathrm{m}$ size fractions could not have contributed to the observed ${ }^{14} \mathrm{C}$-activity in the 0.2 to $1 \mu \mathrm{m}$ fraction. The possibility that cell-fragments of cells broken on the filter could be mistaken for cyanobacteria was checked by sonicating sea water samples from Villefranche bay (May) after incubation with ${ }^{14} \mathrm{CO}_{3}$. Cell counts showed that $83 \%$ of the nanoflagellates disappeared after sonication, while $90 \%$ of the cyanobacteria remained intact. The sonication treatment removed $80 \%$ of the activity from the $>2.0$ $\mu \mathrm{m}$ fraction, which represented $14 \%$ of the total primary production. Since this radioactivity could not be recovered on either 0.6 or $0.45 \mu \mathrm{m}$ filter we believe the contribution of cell fragments in the cyanobacteria fraction to be minor.

\section{Cyanobacteria abundance and population dynamics}

Cyanobacteria numbers varied with time, increasing during the first $12 \mathrm{~h}(12: 00$ to $24: 00 \mathrm{~h})$ from $1.1 \times 10^{4}$ to $3.6 \times 10^{4}$ cells $\mathrm{ml}^{-1}$ (Fig. 1). On the basis of this increase, we can estimate a minimum growth of cyanobacteria (assuming no predation). Converting cell volume to carbon, $5.5 \mu \mathrm{g} \mathrm{C} \mathrm{l}^{-1}$ was produced during $12 \mathrm{~h}$, and this is consistent as a minimum estimate when compared with the cyanobacteria photosynthetic carbon fixation. The cyanobacteria numbers decreased (rather than increased) after the first $12 \mathrm{~h}$, at an average rate of $7.2 \times 10^{2}$ cells ml $\mathrm{ml}^{-1} \mathrm{~h}^{-1}$ despite 2 bursts of division during the next $18 \mathrm{~h}$. Hence the production estimate based on increased cell number during the

Table 1. Primary production in different size fractions of samples from the Villefranche experiment

\begin{tabular}{|c|c|c|c|c|c|}
\hline \multirow[t]{2}{*}{ Time $(\mathrm{h})$} & \multicolumn{4}{|c|}{ Carbon assimilation ( $\left.\mu \mathrm{g} \mathrm{Cl} \mathrm{l}^{-1} \mathrm{~h}^{-1}\right)$} & \\
\hline & Total & $>1 \mu \mathrm{m}$ & $1-0.2 \mu \mathrm{m}$ & Exudate & \\
\hline \multicolumn{6}{|l|}{ Day 1} \\
\hline $09: 00-12.00$ & 1.38 & 0.82 & 0.37 & 0.19 & \\
\hline $12: 00-15: 00$ & 2.04 & 0.88 & 1.09 & 0.07 & \\
\hline $15: 00-18: 00$ & 0.88 & 0.34 & 0.42 & 0.12 & \\
\hline $18: 00-21: 00$ & 0.05 & 0.01 & 0.04 & 0.00 & \\
\hline \multicolumn{6}{|l|}{ Day 2} \\
\hline $06: 00-12: 00$ & 0.34 & 0.07 & 0.15 & 0.12 & $\%$ in $1-0.2 \mu \mathrm{m}$ \\
\hline $12: 00-15: 00$ & 1.36 & 0.68 & 0.28 & 0.40 & fraction \\
\hline $15: 00-18: 00$ & 0.78 & 0.21 & 0.33 & 0.24 & \\
\hline $\begin{array}{l}24 \mathrm{~h} \\
09.00-09.00\end{array}$ & 14.07 & 6.36 & 6.21 & 1.50 & 44 \\
\hline
\end{tabular}


first $12 \mathrm{~h}$ was probably underestimated because of a significant predation pressure on cyanobacteria.

The frequency of dividing cells (FDC) of cyanobacteria showed a maximum of $10 \%$ every $12 \mathrm{~h}$ (18:00, 06:00, 18:00 h) (Fig. 1). Campbell \& Carpenter (1986) used FDC to determine in situ growth rate of cyanobacteria. In this study we lack data to convert our FDC values to growth rates, but have used FDC as an indication of cyanobacterial growth activity. We believe the observed maxima to be valid indicators of bursts of division twice a day. With a standing stock averaging $5.3 \mu \mathrm{g} \mathrm{Cl}^{-1}$, slightly more than one doubling of cyanobacteria per day is required to meet the $8.1 \mu \mathrm{g}$ $\mathrm{C}^{-1} \mathrm{~d}^{-1}$ measured as the net primary production in the $<1 \mu \mathrm{m}$ fraction. In dilution cultures with reduced predation pressure cyanobacteria collected fresh from the sea double once a day at as low as $15^{\circ} \mathrm{C}$ (data not shown). From these results we conclude that the production of cyanobacteria and its dynamics dominated the overall productivity in the carboy. Similar situations have been described in different oligotrophic sea areas (Li et al. 1983, Takahashi et al. 1985, Iturriaga \& Mitchell 1986).

\section{Bacterioplankton abundance and production}

After an initial drop, bacterial numbers increase steadily to $1.1 \times 10^{6}$ cells $\mathrm{ml}^{-1}$ (Fig. 2). Bacterial production was $5.4 \times 10^{5}$ cells $\mathrm{ml}^{-1} \mathrm{~d}^{-1}$, typical of coastal waters. The thymidine uptake data were converted to production using a conservative estimate of the cell carbon content (see 'Material and Methods'), with a resulting production of $5.2 \mu \mathrm{g} \mathrm{C} \mathrm{l^{-1 }} \mathrm{d}^{-1}$ 109:00 to 09:00 h). In order to calculate the amount of substrate needed for the bacterial growth, we assume that the bacterial population is continuously supplied with mainly easily assimilated organic molecules (Hagström et al. 1984). Hence based on a bacterial growth efficiency of $60 \%$ (Payne 1970, Button 1985) $8.3 \mu \mathrm{g} \mathrm{C} 1^{-1}$

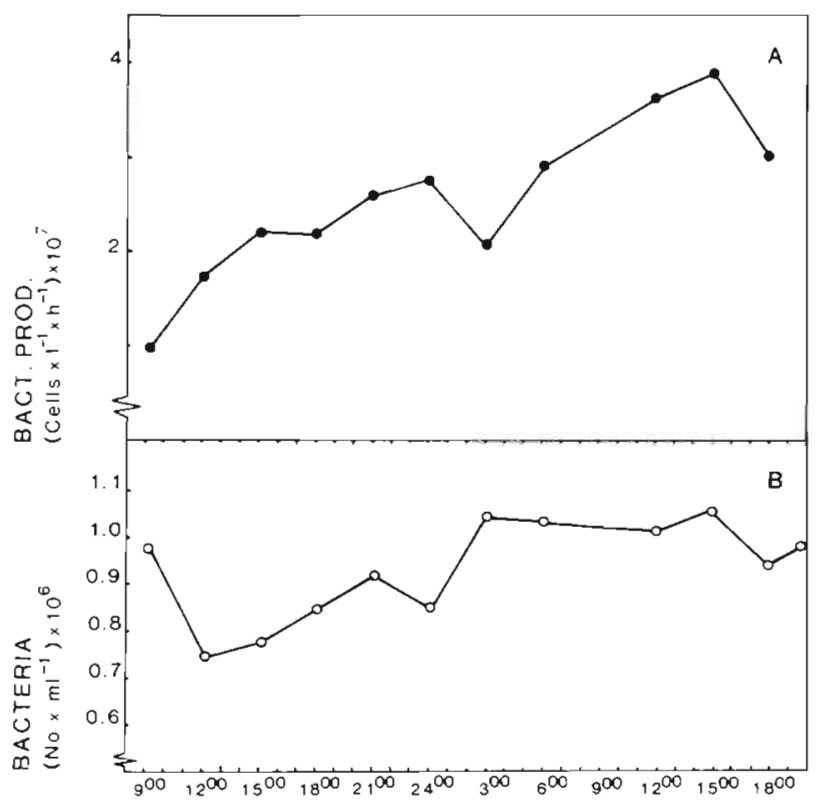

Fig. 2. Diel variation in abundance $(B)$ and production of heterotrophic bacteria (A). SE of bacterial abundances were less than $6 \%$ for all sampling occasions

$\mathrm{d}^{-1}$ would be required to satisfy the measured bacterial production. The measured exudation rate was only 1.5 $\mu \mathrm{g} \mathrm{Cl^{-1 }} \mathrm{d}^{-1}$ so exudation could have satisfied only a part of the bacterial production. We cannot completely rule out the possibility that rapid uptake of exudates was sufficient to support bacterial growth, but we think it to be highly unlikely; it would require that as much as $60 \%$ of the primary production was taken up during the course of the day. This was not the case according to the size fractionated primary production measurements (Table 1). We must therefore ask: what mechanism(s) were responsible for supplying DOM needed to support the measured rate of bacterioplankton production?

Table 2. Predation on bacteria in situ measured using the MiniCap method. Minicells were used as bacterial decoys and the rate of bacterial removal estimated

\begin{tabular}{|c|c|c|c|c|}
\hline Sample & $\begin{array}{l}\text { Predation on bacteria } \\
\quad\left(\times 10^{4} \mathrm{ml}^{-1} \mathrm{~h}^{-1}\right)\end{array}$ & $\begin{array}{l}\text { Production of bacteria } \\
\qquad\left(\times 10^{4} \mathrm{ml}^{-1} \mathrm{~h}^{-1}\right)\end{array}$ & $\begin{array}{l}\text { Ambient bacteria/ } \\
\text { minicell }\left(\times 10^{6} \mathrm{ml}^{-1}\right)\end{array}$ & $\begin{array}{c}\text { Flagellates } \\
\left(\times 10^{3} \mathrm{ml}^{-1}\right)\end{array}$ \\
\hline \multicolumn{5}{|l|}{$84-09-27$} \\
\hline $1 \mathrm{~m}$ Total & 2.2 & - & $0.93 / 0.17$ & - \\
\hline$<12 \mu \mathrm{m}$ & 2.0 & - & $0.93 / 0.17$ & - \\
\hline $\begin{array}{l}84-10-12 \\
\text { Diel study } \\
\text { mean of } 6 \text { expts }\end{array}$ & 2.6 & $2.2^{d}$ & $0.95 / 0.15$ & 2.0 \\
\hline
\end{tabular}




\section{Predation on heterotrophic bacteria and cyanobacteria}

Using the MiniCap technique, 0.55 um diameter minicells serving as bacterial decoys were removed from the water at a rate corresponding to $2.6 \times 10^{4}$ bacteria $\mathrm{ml}^{-1} \mathrm{~h}^{-1}$ (Table 2) (Wikner et al. 1986). This is in good agreement with the bacterial production rate of $2.3 \times 10^{4}$ cells $\mathrm{ml}^{-1} \mathrm{~h}^{-1}$. Thus, growth and predation were balanced for heterotrophic bacterioplankton. Almost all of this predation on bacteria was due to organisms passing a $12 \mu \mathrm{m}$ Nuclepore filter (Table 2). This would indicate that nanoflagellates and small ciliates were the main predators as suggested by others (Haas \& Web 1979, Fenchel 1982, Wright \& Coffin 1984, McManus \& Fuhrman 1986, Rassoulzadegan \& Sheldon 1986). The measured rate of predation correspond to $6.0 \mu \mathrm{g}$ bacterial $\mathrm{C}^{-1} \mathrm{~d}^{-1}$. In order to calculate the predation on cyanobacteria we used the fact that the cyanobacteria decreased during the night, simply assuming that the decrease was a consequence of predation. The number of cyanobacteria consumed corresponds to a predation rate of $7.2 \times 10^{2}$ cells $\mathrm{ml}^{-1} \mathrm{~h}^{-1}$.

The ability of nanoflagellates to utilize cyanobacteria $\left(10^{4}\right.$ cells $\left.\mathrm{ml}^{-1}\right)$ and heterotrophic bacteria $\left(10^{6}\right.$ cells $\mathrm{ml}^{-1}$ ) at a concentration similar to that in the carboy experiment was checked in a separate 2 stage continuous culture experiment. The results presented in Table 3 are mean values of 5 samples from the second stage

Table 3. Selective grazing by nanoflagellates on cyanobacteria and heterotrophic bacteria in a continuous sea water culture, dilution rate $0.015 \mathrm{~h}^{-1}$. Samples were collected daily over a period of 5 consecutive days, and mean values of cells in the in and outflow are compared.

\begin{tabular}{|lccc|}
\hline $\begin{array}{l}\text { Organism } \\
\left(\mathrm{ml}^{-1}\right)\end{array}$ & Inflow & Outflow & $\begin{array}{c}\text { Consumed } \\
(\%)\end{array}$ \\
\hline Cyanobacteria & $6.80 \times 10^{3}$ & $2.80 \times 10^{3}$ & $59(p<0.01)$ \\
Pelagic bacteria & $1.41 \times 10^{6}$ & $1.26 \times 10^{6}$ & $11(p<0.1)$ \\
Flagellate & - & $7.70 \times 10^{3}$ & - \\
\hline
\end{tabular}

chemostat. Flagellates consumed a large fraction of the cyanobacteria (59\% of inflowing cells), when compared to the consumption of heterotrophic bacteria $(11 \%)$. The variation between individual samples was moderate except for the flagellates (mean $=7 \times 10^{3} \mathrm{SD}$ $\pm 2.9 \times 10^{3}, n=5$ ). On the basis of cell volume the consumption of cyanobacteria was almost identical to the consumption of heterotrophic bacteria. From this experiment we conclude that nanoflagellates in nature could consume fast growing cyanobacteria in low numbers so that the turnover rate of cyanobacteria could exceed that of heterotrophic bacteria.

\section{Nanoflagellate and ciliate population dynamics}

Nanoflagellates exhibited 2 cycles of slow decrease followed by a rapid increase in cell numbers. The increase occurred at night between 21:00 and 06:00 h during which time flagellate numbers doubled (Fig. 3).

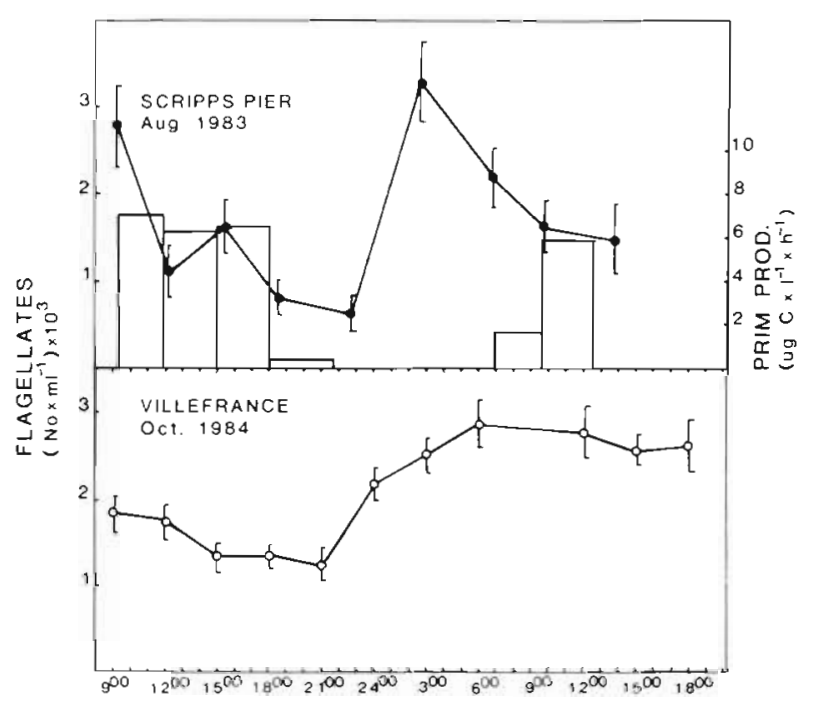

Fig. 3. Variation in flagellate numbers during 24 h at Scripps Pier, August 1983; and in the Villefranche experiment, October 1984 (below). Upper panel shows primary production measured by the ${ }^{14} \mathrm{C}$-method; bars: $\pm \mathrm{SE}$

This diet pattern was also observed in an earlier experiment (Scripps Pier). The net accumulation of flagellate biomass was $4.1 \mu \mathrm{g} \mathrm{Cl}^{-1}$ during the 09:00 to 09:00 h period (flagellate cell volume $19.5 \mu \mathrm{m}^{3}$ ( $n=106$ ), carbon content $0.21 \mathrm{pg} \mathrm{C} \mathrm{mm}^{-3}$; Holligan et al. 1984) while primary production in the $>1 \mu \mathrm{m}$ fraction in which the nanoflagellates were included was $4.5 \mu \mathrm{C} \mathrm{Cl}^{-1} \mathrm{~d}^{-1}$ (Table 1). During the period of decreasing numbers, flagellates disappeared at a rate of $0.17 \mu \mathrm{g} \mathrm{Cl} \mathrm{Cl}^{-1} \mathrm{~h}^{-1}$. Assuming that this rate represents mortality $4.2 \mu \mathrm{g}$ $\mathrm{Cl}^{-1} \mathrm{~d}^{-1}$ must be added to the estimated growth of nanoflagellates. Ciliate numbers showed minor variations during the experiment, but since no obvious trends could be found, we only report the standing crop of ciliates. In order to link predation by ciliates to the population dynamics of the flagellates we have assumed a growth requirement based on cultured ciliates from the same area (Sheldon et al. 1986) (Table 4).

\section{Sources of DOM for bacterial growth}

The largest standing stock was that of the bacterioplankton $\left(9.7 \mu \mathrm{g} \mathrm{Cl}^{-1}\right)$ and its growth consumed $8.3 \mu \mathrm{g}$ $\mathrm{C}^{-1} \mathrm{~d}^{-1}$ (Table 4 ). The primary production rate was 
Table 4. Compilation of data used to formulate the structure of a microbial foodweb, as seen in Fig. 4

\begin{tabular}{|c|c|c|c|}
\hline $\begin{array}{l}\text { Organism or } \\
\text { carbon-source }\end{array}$ & $\begin{array}{l}\text { Standing crop } \\
\left(\mu \mathrm{g} \mathrm{Cl} \mathrm{l}^{-1}\right)\end{array}$ & 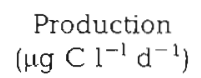 & $\begin{array}{l}\text { Growth need } \\
\left(\mu g \mathrm{Cl}^{-1} \mathrm{~d}^{-1}\right)\end{array}$ \\
\hline \multicolumn{4}{|l|}{ Autotrophic: } \\
\hline DOM & - & 1.6 & - \\
\hline Eukaryot. algae & - & 4.5 & -- \\
\hline Cyano bact. & 5.3 & 8.1 & - \\
\hline \multicolumn{4}{|l|}{ Heterotrophic: } \\
\hline Bacteria & 8.7 & 5.2 & 8.3 \\
\hline Nanoflagellates & 9.7 & 8.4 & 16.8 \\
\hline Ciliates & 2.4 & $2.4^{\circ}$ & $5.9^{\cdots}$ \\
\hline \multicolumn{4}{|c|}{$\therefore=$ Assumed generation time, $24 \mathrm{~h}$} \\
\hline
\end{tabular}

only $14.1 \mu \mathrm{g} \mathrm{C} \mathrm{l}^{-1} \mathrm{~d}^{-1}$; hence about $60 \%$ of the primary production was required for bacterial growth. This raises the question of what mechanisms channel $60 \%$ of primary production into bacteria. We therefore outlined a mass-balance model to illustrate routes that could explain this transfer. In our calculations we do not make the distinction between autotrophic and heterotrophic flagellates. Instead we consider these to be 2 sides of the same mixotrophic group of organisms (Estep et al. 1986). For practical reasons, however, this means that they must be included in 2 functional categories in the carbon budget. Furthermore, although we only measured abundance of ciliates, a second higher trophic level (microplankton) was included according to the presence of ciliates and their previously found growth requirements in laboratory experiments (Sheldon et al. 1986).

In Fig. 4, we set the rate of primary production at an arbitrary level of 100 ; other fluxes are relative to this. DOM $\rightarrow$ Bacteria flux with a magnitude of 63 units is based on actual, conservative, measure of bacterial production. Primary production (100 units) was dominated by cyanobacteria (57 units); exudation was 11 , and production by other-than-cyanobacteria was 32 . We can see only 2 alternatives for transferring $60 \%$ of primary production to the DOM pool. (A) Exudation of $60 \%$ of primary production and the uptake of this amount of ${ }^{14} \mathrm{C}$ exudates during the $3 \mathrm{~h}$ incubation. This would require an absolute coupling between exudation and uptake, as well as an unreasonably high exudation rate. (B) Bacterivorous flagellates and small ciliates utilize virtually all cyanobacteria and heterotrophic bacteria production; they release about half of the ingested organic carbon due to incomplete assimilation of food particles in the feeding vacuoles and/or by senescence and mortality. We favour alternative $B$ as being in better accord with the observations.

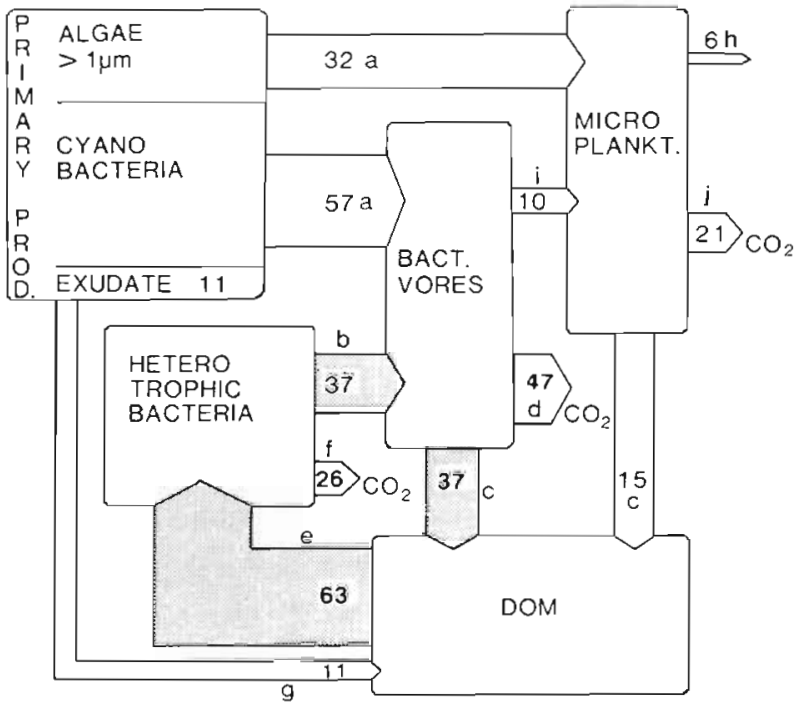

Fig. 4. Organic fluxes in the cyanobacteria-dominated microbial loop. Mass-balance model based on the Villefranche experiment. a: Transfer of carbon from cyanobacteria and algae $>1 \mu \mathrm{m}$ into bacterivores and microplankton. b: Predation on bacteria measured by the MiniCap method. c: Transfer of carbon from bacterivores and microplankton into DOM. d: Respiration calculated using $50 \%$ growth efficiency for the flagellates. e: Required DOM supply for bacterial secondary production when $60 \%$ growth efficiency for the bacteria is taken into account. $\mathrm{f}$ : Bacterial respiration. g: Production of organic exudate measured by the ${ }^{14} \mathrm{C}$-method $\mathrm{h}$ : Transfer of carbon to higher trophic levels. i: Transfer of carbon from bacterivores into microplankton. j: Microplankton respiration

\section{Organic fluxes in cyanobacteria-dominated microbial loop}

The importance of heterotrophic bacteria as a sink or link in the pelagic ecosystem has been focused around the question whether or not bacteria are important as 
food for higher trophic levels (metazoans) (Ducklow et al. 1986). Our observations suggest that in ecosystems where cyanobacteria are the dominant primary producers, consumption of cyanobacteria by protozoa plays a pivotal role in mediating organic fluxes from primary producers to heterotrophic bacterioplankton (see also Iturriaga \& Mitchell 1986). According to our model the main flux route is cyanobacteria carbon into bacterivores although a substantial part of heterotrophic bacteria is concomitantly consumed. A substantial fraction of the bacterivore and the microplankton carbon is released by excretion and cell lysis, to be used by the heterotrophic bacterioplankton. About $86 \%$ of the autotrophic production is balanced by respiration due to heterotrophic bacteria and protozoa, leaving $6 \%$ of the primary production to higher trophic levels. This scenario should apply to ecosystems where bacterial production rate is high and comparable to primary production, and the dominant primary producers are cyanobacteria. A significant fraction of the photosynthetically fixed carbon will be mineralized within a simple microbial loop, thus rendering it an energy sink in the foodweb (Pomeroy 1974). This would be in accordance with the view that: In ecosystems where the material flux is dominantly via the microbial loop the vertical flux of material is slow (due to small size of the organisms in the microbial loop) (Azam \& Cho 1987). In the sink and/or link context, pelagic bacteria exploit organic waste in the system and build nutrient rich biomass utilized as food by the protozoa that excrete inorganic nutrients for the autotrophs to use.

Acknowledgements. This work was made possible by grants CNRS-PIRO AIP953146-GRECO P4-UA.716 (Rassoulzadegan), NFR B-BU 4452-117 (Hagström) and NSF OCE 85-01363 (Azam)

\section{LITERATURE CITED}

Ammerman, J. W., Fuhrman, J. A., Hagström, А., Azam, F (1984). Bacterioplankton growth in seawater: I. Growth kinetics and cellular characteristics in seawater cultures. Mar. Ecol. Prog. Ser. 18: 31-39

Andersson, A., Larsson, U., Hagström, A. (1986). Size selective grazing by a microflagellate on pelagic bacteria. Mar. Ecol. Prog. Ser. 33: 51-57

Azam, F., Cho, B. C. (1987). Bacterial utilization of organic matter in the sea. In: SGM41, Ecology of microbial communities. Cambridge University Press, Cambridge, p $261-281$

Azam, F., Fenchel, T., Field, J. G., Gray, J. S., Meyer-Reil, L. A., Thingstad, F. (1983). The ecological role of watercolumn microbes in the sea. Mar. Ecol. Prog. Ser. 10 $257-263$

Bjørnsen, P. K. (1986). Automatic determination of bacterioplankton biomass by image analysis. Appl. environ. Microbiol. 51: 1199-1204

Bratbak, G. (1985). Bacterial biovolume and biomass estimation. A.ppl environ. Microbiol. 49: 1488-1493
Button, D. K. (1985). Kinetics of nutrient-limited transport and microbial growth. Microb. Rev. 49: 270-297.

Campbell, L., Carpenter, E. J. (1986). Diel patterns of cell division in marine Synechococcus spp. (cyanobacteria): use of frequency of dividing cells technique to measure growth rate. Mar. Ecol. Prog. Ser. 32: 139-148

Ducklow, H. W., Purdie, D. A., Williams, LeB P. J., Davis, J. M. (1986). Bacterioplankton: a sink for carbon in a coastal marine plankton community. Science 232: 865-867

Estep, K. M., Davis, P. G., Keller, M. D., Sieburth, McN. J (1986). How important are oceanic algal nanoflagellates in bacterivory? Limnol. Oceanogr. 31: 646-650

Fenchel, T. (1982). Ecology of heterotrophic microflagellates IV Quantitative occurrence and importance as bacterial consumers. Mar. Ecol. Prog. Ser. 9: 35-42

Fuhrman, J. A., Azam, F. (1980). Bacterial secondary production estimates for coastal waters of British Columbia Antarctica and California. Appl. environ. Microbiol. 39 1085-1095

Fuhrman, J. A., Azam, F. (1982). Thymidine incorporation as a measure of heterotrophic bacterioplankton production in marine surface waters: Evaluation and field results. Mar. Biol 66: 109-120

Gargas, E. (ed.) (1975). A manual for phytoplankton primary production studies in the Baltic. Publs. Baltic mar. Biologists 2,1-88. (Copies from Water Quality Institute, DK-2970 Horsholm, Denmark)

Haas, L. W., Webb, K. L. (1979). Nutritional mode of several non-pigmented microflagellates from the York river estuary, Virginia, J. exp. mar. Biol. Ecol. 39: 125-134

Hagström, §., Larsson, U., Hörstedt, P., Normark, S. (1979). Frequency of dividing cells, a new approach to the determination of bacterial cell growth rates in aquatic environments. Appl. environ. Microbiol. 37(5): 805-812

Hagström, A., Ammerman, J. A., Henrichs, S., Azam, F. (1984). Bacterioplankton growth in seawater: II. Organic matter utilization during steady-state growth in seawater cultures. Mar. Ecol. Prog. Ser. 18: 41-48

Hobbie, J. E., Daley, R. J., Jasper, S. (1977). Use of Nuclepore filters for counting bacteria by epifluorescence microscopy. Appl. environ. Microbiol. 33: 1225-1228

Holligan, P. M., Harris, R. P., Newell, R. C., Harbour, D. S. Head, R. N., Linley, E. A. S., Lucas, M. I., Tranter, P. R. G, Weekley, C. M. (1984). Vertical distribution and partitioning of organic carbon in mixed, frontal and stratified waters of the English Channel. Mar. Ecol. Prog. Ser. 14: $111-127$

Iturriaga, R., Mitchell, B. G. (1986). Chrococcoid cyanobacteria: a significant component in the food web dynamics of the open ocean. Mar. Ecol. Prog. Ser. 28: 291-297

Joint, I. R., Pomeroy, A. J. (1983). Production of picoplankton and small nanoplankton in the Celtic Sea. Mar. Biol. 77: 19-27

Larsson, U., Hagström, $\AA$. (1982). Fractionated phytoplankton primary production, exudate release and bacterial production in a Baltic eutrophication gradient. Mar Biol. 67: $57-70$

Laws, E. A., Redalje, D. G., Haas, L. W., Bienfang, P. K. Eppley, R. W., Harrison, W. G., Karl, D. M., Marra, J (1984). High phytoplankton growth rates in oligotrophic Hawaiian coastal waters. Limnol. Oceanogr. 29(6): 1161-1169

Lee, S., Fuhrman, J. A. (1987). Relationships between biovolume and biomass of naturally derived marine bacterioplankton. Appl. environ. Microbiol. 53: 1298-1303

Li, W. K. W., Subba Rao, D. V., Harrison, W G., Smith, J. C., Cullen, J. J., Irwin, B., Platt, T (1983). Autotrophic picoplankton in the tropical ocean. Nature, Lond. 219: 292-295 
McManus, G. B., Fuhrman, J. A. (1986). Bacterivory in seawater studied with the use of inert fluorescent particles. L.imnol. Oceanogr 31(2): 420-426

Payne, W. J. (1970). Energy yields and growth of heterotrophs Ann. Rev. Microbiol. 24: 17-52

Pomeroy, L. R. (1974). The ocean's food web, a changing paradigm. BioScience 24: 499-504

Porter, K. G., Feig, Y S. (1980). The use of DAPI for identifying and counting aquatic microflora. Limnol. Oceanogr 25: 943-948

Rassoulzadegan, F., Sheldon, R. W. (1986). Predator-prey interactions of nanozooplankton and bacteria in an oligotrophic marine enrivonment. Limnol. Oceanogr 31: $1010-1021$

Rassoulzadegan, F., Gostan, J. (1976). Repartition des ciliés pélagiques dans les eaux de Villefranche-Sur-Mer remarques sur la dispersion du microzooplankton en mer et a léinténur des échantillions dénombrés par la méthod d'Utermöhl. Ann. Inst. oceanogr. 52(2): 175-188

Sheldon, R. W., Nival, P., Rassoulzadegan, F. (1986). An experimental investigation of a copepod-ciliate-flagellate food chain with some observations relevant to the linear biomass hypothesis. Limnol. Oceanogr. 31(1): 184-188

Takahashi, M., Kikuchi, K., Hara, Y (1985). Importance of picocyanobacteria biomass (unicellular, blue-green algae) in the phytoplankton population of the coastal waters of Japan. Mar. Biol. 89: 63-69

Wikner, J., Andersson, A., Normark, S., Hagströrn, $\AA$. (1986). Use of genetically marked minicells, a probe to measure predation in aquatic environments. Appl. environ. Microbiol. 52(1): 4-8

Wright, R. T., Coffin, R. B. (1984), Measuring microzooplankton grazing on planktonic marine bacteria by its impact on bacterial production. Microb. Ecol. 10: 137-149

This article was submitted to the editor; it was accepted for printing on August 1, 1988 